\title{
Physicochemical and sensory characteristics of soft cheese as affected by different salt levels \\ ${ }^{2}$ Koranteng, B. A., ${ }^{* 1}$ Awodoyin O.R., ${ }^{1}$ Adediran, A. O. and ${ }^{1}$ Omojola A. B. \\ * Animal Products and Processing Unit, Department of Animal Science, University of Ibadan \\ ${ }^{2}$ College of Agriculture and Natural Resources, Department of Animal Sciences, Kwame Nkrumah University of Science and Technology, Ghana *Corresponding author: kasyem@yahoo.com; +2348027290842 \\ Abstract
}

Cheese, a nutrient-dense dairy food is very rich in protein and calcium. Salting during cheese production is an important step because its concentration is the major factor that influences the organoleptic quality especially flavour. In order to accommodate increasing demands for reduced-sodium cheese without compromising palatability and safety, it is therefore imperative to assess the effect of different salt levels that will produce good quality cheese. Raw milk was obtained from Gudali, Mali and Burkina cows at the Cattle and Dairy Research Station-Bodi, Ashanti, Ghana. There were five treatments and each consists of 1000 $m L$ of milk, $2.5 \mathrm{~mL}$ of juice from Calotropis procera as coagulant and graded levels of salt (0, $4,8,12,16 \mathrm{~g})$. Cheese was produced using standard procedure. Yield (\%), proximate composition (\%) mineral contents (sodium, chlorine, calcium, phosphorus) and texture profile analysis (adhesiveness, chewiness, cohesiveness elasticity, firmness, gumminess resilience was assessed on freshly prepared cheese. The result revealed that cheese $p H$ slightly increased as salt concentration increased. The moisture of $T_{2}(59.47)$ and $T_{3}(58.70)$ were not significantly $(P>0.05)$ different but these were different from $T_{1}(54.67), T_{4}(56.60)$, $T_{5}(50.37)$. The crude protein contents of $T_{3}(16.36)$ and $T_{1}(15.68)$ were significantly higher $(P<0.05)$ than $T_{2}(13.90), T_{4}(10.77)$ and $T_{5}(10.32)$. The fat contents of $T_{4}(14.41)$ and $T_{5}$ (17.28) were significantly higher $(P<0.05)$ compared with others. The yield (33.64) and calcium content (1.49) of $T_{3}$ and phosphorus content (2.35) of $T_{5}$ were significantly higher $(P<0.05)$ than others. The texture profile analysis indicated that the adhesiveness, cohesiveness and resilience of cheese $T_{4}$ and $T_{5}$ were significantly lower $(P<0.05)$; while the chewiness, elasticity, firmness and gumminess of $T_{4}$ and $T_{5}$ were significantly higher $(P<0.05)$. The study revealed that cheese with salt inclusion level of $8 g\left(T_{3}\right)$ possesses the characteristics of a good quality cheese.

Keywords: Cheese, concentration, sodium chloride, yield, texture profile

\section{Caractéristiques physicochimiques et sensorielles du fromage à pâte molle telles qu'affectées par différents niveaux de sel}

\section{Résumé}

Le fromage, un aliment laitier riche en nutriments, est très riche en protéines et en calcium. Le salage lors de la fabrication du fromage est une étape importante car sa concentration est le facteur majeur qui influence la qualité organoleptique en particulier la saveur. Afin de répondre à la demande croissante de fromages à faible teneur en sodium sans compromettre l'appétence et la sécurité, il est donc impératif d'évaluer l'effet des différents niveaux de sel qui produiront un fromage de bonne qualité. Le lait cru a été obtenu à partir de vaches Gudali, Mali et Burkina à la Bovin et Station de recherche laitière-Bodi, Ashanti, Ghana. Il y 


\section{Quality evaluation of soft cheese as affected by graded levels of salt}

avait cinq traitements et chacun se compose de $1000 \mathrm{ml}$ de lait, 2,5 $\mathrm{ml}$ de jus de Calotropisprocera comme coagulant et des niveaux gradués de sel (0, 4, 8, 12, 16 g). Le fromage a été produit en utilisant une procédure standard. L'analyse du rendement (\%), de la composition approximative (\%) des teneurs en minéraux (sodium, chlore, calcium, phosphore) et du profil de texture (adhésivité, mastication, cohésion, élasticité, fermeté, résistance à la gomme a été évaluée sur du fromage fraîchement préparé. Le résultat a révélé que le $\mathrm{pH}$ du fromage légèrement augmenté avec l'augmentation de la concentration en sel. $L$ 'humidité de T2 $(59,47)$ et T3 $(58,70)$ n'étaient pas significativement différentes $(P>0,05)$ mais elles étaient différentes de T1 (54,67), T4 (56,60), T5 (50,37). les teneurs en protéines de $T 3(16,36)$ et $T 1(15,68)$ étaient significativement plus élevées $(P<0,05)$ que celles de T2 (13,90), T4 $(10,77)$ et T5 $(10,32)$ Les teneurs en graisses de T4 $(14,41)$ et T5 $(17,28)$ étaient significativement plus élevé $(P<0,05)$ par rapport aux autres. Le rendement $(33,64)$ et la teneur en calcium $(1,49)$ de T3 et la teneur en phosphore (2,35) de T5 étaient significativement plus élevés $(P<0,05)$ que les autres. L'analyse du profil de texture a indiqué que le l'adhésivité, la cohésion et la résilience des fromages T4 et T5 étaient significativement plus faibles $(P<0,05)$; tandis que la mastication, l'élasticité, la fermeté et la gomme des T4 et T5 étaient significativement plus élevées $(P<0,05)$. L'étude a révélé que le fromage avec un taux d'inclusion de sel de $8 g$ (T3) possède les caractéristiques d'un fromage de bonne qualité. Mots-clés : Fromage, concentration, chlorure de sodium, rendement, profil de texture

\section{Introduction}

Cheese is a nutrient-dense dairy food that is rich in protein, calcium and offers consumer large diversity in flavour, texture, appearance, cooking properties and usage applications (McCarthy et al., 2015). Salting is an important step in cheese and traditionally common (sodium chloride) is the main source in cheese (El-Bakry, 2012). Salt in cheese is of utmost importance to microbial and enzyme activities and directly contributes to organoleptic quality especially flavour (Habib, 2015). It imparts saltiness, enhances mouth-feel and balancing while suppressing off-flavours (bitterness) thus the overall palatability of cheese (Breslin and Beauchamp, 1997). However, its concentration is one of the most important factors influencing the overall quality of cheese (Guo et al., 1997; Paulson et al., 1998). This is because texture development, casein hydration and conformation during cheese production behave in a concentration-dependent manner (Guinee and Fox, 2004). Therefore, in order to accommodate increasing demands for cheese with reduced sodium without compromising safety and palatability, it is imperative to assess the effect of different salt levels that will produce cheese of good quality. In this study, cheese trial was designed to investigate the isolated effect of salt $(\mathrm{NaCl})$ on yield and nutrient composition of soft cheese made from cow milk using coagulants of plant origin Calotropis procera (Sodom apple).

\section{Materials and methods Sample collection}

The raw cow milk for the cheese production was obtained from three dairy animals Gudali, Mali and Burkina cows at the Cattle and Dairy Research Station-Bodi in the Ashanti region of Ghana republic.

\section{Milk collection}

The environment and the milking parlour were thoroughly cleaned prior to milking. The animals were hand milked into plastic buckets and immediately clarified into sterilized screw capped bottles by the use of net sieve and cheese cloth to remove any dirts/ debris/sediments. The appearance and temperature (using a thermometer) of the 


\section{Koranteng, Awodoyin, Adediran and Omojola}

milk immediately after milking was observed and recorded. The milk was transported to the Department Animal Science (Animal Products unit laboratory) Kwame Nkrumah University of Science and Technology in ice parked containers to keep the temperature low and suppress microbial growth. On arrival at the department, the milk was kept in a refrigerator to keep it as cool as possible and the temperature of the milk taken after preservation $\left(22^{\circ} \mathrm{C}\right)$. After cooling, the milk was thoroughly mixed together for homogeneity and samples were taken for further analysis on the raw milk.

\section{Preparation of juice from Calotropis} procera (Sodom Apple juice (SAJ))

The extraction of juice was achieved by following the procedures of Hussain et al. (2014). The Calotropis procera (sodom apple leaves (SAJ)) were washed, drained and grinded with electric blender. The juice was separated from the shaft by squeezing out through muslin cloth into a clean medium bowl previously rinsed with distilled water. The extracted juice was placed in water bath at a temperature of $82^{\circ} \mathrm{C}$ for 30 minutes.

\section{Soft cheese production}

There were five treatments and each consists of $1000 \mathrm{~mL}$ of milk, $2.5 \mathrm{ml}$ of SAJ and graded levels of salt: $0 \mathrm{~g}\left(\mathrm{~T}_{1}\right), 4 \mathrm{~g}\left(\mathrm{~T}_{2}\right), 8 \mathrm{~g}$ $\left(\mathrm{T}_{3}\right), 12 \mathrm{~g}\left(\mathrm{~T}_{4}\right), 16 \mathrm{~g}\left(\mathrm{~T}_{5}\right)$. The production of soft cheese was carried out according to the method of Shahein et al. (2014). Milk was homogenized and pasteurized at $72^{\circ} \mathrm{C}$ for 15 seconds in a water bath and allowed to cool down immediately to $39 \pm 1{ }^{\circ} \mathrm{C}$ in order to reduce the temperature of the starter bacteria growth. The salt was first added to the warm milk to ensure uniform distribution of the salt. The SAJ was then added and the mixture was gently heated again, stirred gently and intermittently, and allow to coagulate (in about 3 hours). The obtained curd was transferred to perforated cheese molds over night to facilitate the removal of all the whey and form a characteristic cheese shape. The cheese was immediately weighed (wet weight) and then stored at $4^{\circ} \mathrm{C}$ and the whey was also neatly packed for further analysis. All analysis was carried out at the laboratory of Department Animal Science, College of Agriculture and Natural Resources, Kwame Nkrumah University of Science and Technology.

\section{Parameters measured}

Raw milk was analyzed for lactose, total protein, density, non-solid fat, temperature, freezing point, conductivity (lactoscan analyzer MCC50 serial number 31069) and fat content as described by Marshal (1993). Total solids were determined following the procedure of Madadlou et al. (2006). The $\mathrm{pH}$ was measured with a digital $\mathrm{pH}$ meter (Mettler-Toledo GmbH, Schwerzenbach, Switzerland) by directly inserting the $\mathrm{pH}$ electrode probe into the mixture (Upreti et al., 2004).

\section{Yield}

The cheese obtained from each of the treatment was weighed immediately after draining off the whey using a weighing balance (Mettler H33 AR type). Apparent yield was calculated as follows: the weight of cheese in $\mathrm{g} / 1000 \mathrm{~g}$ of milk/ weight of milk used

$\%$ Cheese Yield $=$

Yield of cheese produced $(\mathrm{g})$ × 100

Weight of milk used (g)

\section{Chemical analysis}

Chemical analysis of cheese samples was carried out on zero day. The $\mathrm{pH}$ was determined through direct insertion into cheese with a $\mathrm{pH}$ potentiometer. Temperature was determined by direct insertion of a digital laboratory thermometer. The proximate and total solids were carried out following standard methods of AOAC (2000), Total protein in cheese was determined according to Yuanrong et al. (2016) by measuring total nitrogen using the Kjeldahl method (AOAC 


\section{Quality evaluation of soft cheese as affected by graded levels of salt}

2000) with a Kjeltec Auto Analyzer (Model 2400, Tecator, Hoganas, Sweden) and converting with a multiplication factor of 6.38. Fat contents were determined by Soxhlet Extraction method. All analysis was done in triplicates. Total amounts of sodium (Na), Chloride (Cl), Phosphorus (P) and Calcium $(\mathrm{Ca})$ contents of laboratory produced cheese samples were analyzed in triplicates by atomic absorption and emission spectroscopy $(\mathrm{Na} ; 3300$ Spectrometer, Perkin Elmer, Waltham, MA) according to ISO-IDF (2007), colorimetric method (P) (AFNOR, 1985).

Texture profile analysis

Textural attributes were measured by the Texture Profile Analysis (TPA) method, by using a double compression test following the procedure of Sandoval-Copado et al. (2016). A texturometer (Shimadzu EZ-Test, Kyoto, Japan) was employed, using Rheometer v2.05 software (Shimadzu). Cheese was cut parallel to the longitudinal orientation of fibers into $25 \times 25 \times 8 \mathrm{~mm}$ pieces. Cheese temperature at the time of analysis was $16 \pm 2^{\circ} \mathrm{C}$. The test parameters used were ascent velocity $50 \mathrm{~mm} / \mathrm{min}$, descent velocity $50 \mathrm{~mm} / \mathrm{min}$, compression distance $3 \mathrm{~mm}$, recovery time 5 seconds and 2 compressions. Attributes measured were firmness, adhesiveness, cohesiveness, gumminess, springiness/elasticity, resilience and chewiness. Each measurement was performed in sextuplicates.

Table 1: Composition of milk used for soft cheese production

\begin{tabular}{lll}
\hline Parameters & Range of values & Mean Values \\
\hline Fat (\%) & $4.50-4.58$ & 4.54 \\
Non-solid fat (\%) & $8.67-8.70$ & 8.69 \\
Density (\%) & $30.19-30.33$ & 30.25 \\
Lactose (\%) & $4.77-4.79$ & 4.78 \\
Total Protein (\%) & 3.18 & 3.18 \\
Total solids (\%) & $13.20-13.27$ & 13.23 \\
Added water (\%) & 0.00 & 0.00 \\
pH & $6.90-7.12$ & 6.99 \\
Temperature of sample $(\mathrm{C})$ & $22.67-52.84$ & 22.75 \\
Freezing point $\left({ }^{\circ} \mathrm{C}\right)$ & $-0.561-(-0.562)$ & -0.562 \\
Conductivity & $3.42-3.51$ & 3.46 \\
\hline
\end{tabular}

Source by: Lactoscan analyzer MCC50 serial number 31069

\section{Results and discussion}

\section{Coagulation time and temperature}

In this study the coagulation temperatures (Table 2) were 81. 33, 85.00, 87.00, 87.67, $90.67 \mathrm{C}$ and time were $30.00,52.00,64.00$, 75.00 and 89.67 minutes for $T_{1}, T_{2}, T_{3}, T_{4}$ and $\mathrm{T}_{5}$, respectively. It was observed that during cheese production, the coagulation temperature and time increases as the salt level increases. There was a mild increase in cheese pH $6.59\left(\mathrm{~T}_{1}\right), 6.60\left(\mathrm{~T}_{2}\right), 6.63\left(\mathrm{~T}_{3}\right)$, $6.65\left(\mathrm{~T}_{4}\right)$ and $6.77\left(\mathrm{~T}_{5}\right)$ (although not significant) as salt level increases and this agrees with the report of Moller et. al. (2013) who reported a slight increase in the $\mathrm{pH}$ of cheese with high salt concentration.

Table 2: The $\mathrm{pH}$ and coagulation (time and temperature) of freshly prepared soft cheese as affected by graded levels of sodium chloride

\begin{tabular}{lcccccc}
\hline Parameters & $\mathrm{T}_{1}$ & $\mathrm{~T}_{2}$ & $\mathrm{~T}_{3}$ & $\mathrm{~T}_{4}$ & $\mathrm{~T}_{5}$ & SEM \\
\hline $\mathrm{pH}$ & 6.59 & 6.60 & 6.63 & 6.65 & 6.67 & 0.04 \\
Coagulation Temperature $\left({ }^{\circ} \mathrm{C}\right)$ & $81.33^{\mathrm{c}}$ & $85.00^{\mathrm{c}}$ & $87.00^{\mathrm{b}}$ & $87.67^{\mathrm{b}}$ & $90.67^{\mathrm{a}}$ & 0.87 \\
Coagulation Time (minutes) & $30.00^{\mathrm{e}}$ & $52.00^{\mathrm{d}}$ & $64.00^{\mathrm{c}}$ & $75.00^{\mathrm{b}}$ & $89.67^{\mathrm{a}}$ & 5.45 \\
\hline abcd Means in the same row with different superscript are significantly different $(\mathrm{P}>0.05)$
\end{tabular}




\section{Koranteng, Awodoyin, Adediran and Omojola}

\section{Chemical composition}

Moisture, protein and fat were the three major constituents of cheese, which directly affect its textural and functional properties (Yates and Drake, 2007). The chemical composition of the soft cheese produced in this study is displayed in table 3 . The moisture contents obtained in this study were $54.6759 .47,58.70,56.60$ and 50.37 for $\mathrm{T}_{1}, \mathrm{~T}_{2}, \mathrm{~T}_{3}, \mathrm{~T}_{4}$ and $\mathrm{T}_{5}$ respectively. It was noticed that as the salt inclusion increases, the moisture contents decreases. This could be as a result of the outward diffusion of water and simultaneous inward diffusion of salt (Moller et al., 2013) as the salt contents increases which will cause a reduction in the moisture content of the final cheese. This also agrees with the report of Irigoyen et al. (2002) and Everard et al. (2007) that increase in salt level of cheese will result in a decrease moisture content. The moisture contents of cheese obtained in this study ranged approximately from $50-59 \%$ of total mass which is higher than approximately $50 \%$ obtained by Yuanrong et al. (2016). The protein and fat contents were $\mathrm{T}_{1}(13.90$, 7.71), $\mathrm{T}_{2}(15.68,7.96), \mathrm{T}_{3}(16.36,9.21)$, $\mathrm{T}_{4}(10.77,14.41)$ and $\mathrm{T}_{5}(10.32,17.28)$, respectively. There was no significant difference $(\mathrm{P}>0.05)$ in the protein contents of $T_{2}$ and $T_{3}$ but these are significantly different $(\mathrm{P}<0.05)$ from $\mathrm{T}_{1}, \mathrm{~T}_{4}$ and $\mathrm{T}_{5}$. The fat contents of $T_{4}$ and $T_{5}$ were not significant $(\mathrm{P}>0.05)$ but these were significantly different $(\mathrm{P}<0.05)$ from $\mathrm{T}_{1}, \mathrm{~T}_{2}$ and $\mathrm{T}_{3}$. The yield of $\mathrm{T}_{3}$ (33.64) is significantly different from $\mathrm{T}_{1}$ (28.54), $\mathrm{T}_{2}$ (24.35), $\mathrm{T}_{4}$ (22.39) and $\mathrm{T}_{5}$ (16.33). It was expected that as the moisture content of the cheese decreases, the protein contents should also increase because expulsion of water from the cheese will favour protein-protein interaction and results in a more compact protein matrix (Zisu and Shah, 2005). Although this increase in protein occurred up to the inclusion level of $8 \mathrm{~g}$ of salt but start to decrease drastically at $12 \mathrm{~g}$ and $16 \mathrm{~g}$ inclusion levels. Fat content of cheese is usually responsible for desirable functional, textural, and sensory properties of cheese (Van Hekken et al., 2013). It was noticed that increase in salt inclusion in cheese production in this study resulted in simultaneous increase in the fat contents. The fat contents of the cheese ranged from $7.71-17.28 \%$ which is lower than 22.5$51.7 \%$ (Fat in Dry Matter) obtained by Yuanrong et al. (2016) and 20-22\% (Sandoval-Copad et al., 2016).

The protein contents (10.32-16.36\%) obtained in this study were lower than 16$18.5 \%$ (Yuanrong et al., 2016) and 44.5\% (Fashakin and Unokiwedi, 1992) for cheese with added melon milk but higher than 5.33\% (Frazier and Westhoff, 1988) and $12.86 \%$ (Uaboi-Egbenni et al., 2010). However, the values obtained in this study were within the range of $8.90 \%-14.90 \%$ and $6.23 \%-14.30 \%$ reported by Nour El Diam and El Zubeir (2010) for cheese processed from milk with $2.2 \%$ and $4.4 \%$ fat respectively. These differences in chemical analysis could be attributed to various factors such as raw milk composition, curd handling, cooking and salting which are basic factors that influenced chemical composition of cheese (Ak and Gunasekaran, 2002). For instance, if the curd is stirred for a longer time during acidification, more whey is expelled and the resulting cheese will have low moisture content (Irigoyen et al., 2002; Everard et al., 2007).

The total solids (33.07-49.40) of some of the cheese in this study falls within the range of $46 \%$ (Coppola et al.,1995), $47.82 \%$ (Elkoussy et al., 1995) and 49.50\% (Fernadez and Kosikowski, 1986). On the other hand, these values are lower than 50\% and 52\% obtained by Abdel Moneim (2012) at zero day; for cheese produced from cow milk and mixture of cow and goat milk respectively and also lower than $51.42 \%$ 


\section{Quality evaluation of soft cheese as affected by graded levels of salt}

and $54.52 \%$ reported by El Owni and Sana (2009). This differences in total solids contents could be attributed to the high variation of fat content of cheese as $(\mathrm{El}$ Owni and Sana, 2009; Nour El Diam and El Zubeir, 2010).

\section{Yield}

Salt reduction in cheese is generally manifested in quantitative than qualitative effects (Moller et al., 2013). The high yield (table 3 ) recorded for cheese with inclusion level of $4 \mathrm{~g}$ and $8 \mathrm{~g}$ salt could be attributed to the high moisture content recorded in these two cheeses which is assumed to have added to the weight of the cheese. The low yield of cheese from $12 \mathrm{~g}$ and $16 \mathrm{~g}$ salt inclusions could be as a result of its low moisture contents which is assumed to be due to outward diffusion of water and simultaneous inward diffusion of salt as salt inclusion increases; this results in a reduction in the moisture content of the final cheese (Moller et al., 2013) hence low yield. The yield of cheese obtained in this study ranged between $16.33-33.64 \%$. Some of these values are within the values of $18.20 \%, 19.36 \% 25.60 \%$ obtained by Ogunlade et al. (2017) and 20.92\%, $26.91 \%, 28.01 \%$ obtained by Akinloye and Adewumi (2014) when lemon juice, Carica papaya and Calotropis procera juice in this order were used as coagulants. The variation in yield could be as a result of type of coagulants and source of milk (Ogunlade et al., 2017) or method of processing (El Owni and Sana, 2009).

Table 3: Yield and chemical composition of fresh soft cheese with graded levels of sodium chloride

\begin{tabular}{lcccccc}
\hline Parameters (\%) & $\mathrm{T}_{1}$ & $\mathrm{~T}_{2}$ & $\mathrm{~T}_{3}$ & $\mathrm{~T}_{4}$ & $\mathrm{~T}_{5}$ & SEM \\
\hline Moisture & $54.67^{\mathrm{c}}$ & $59.47^{\mathrm{a}}$ & $58.70^{\mathrm{a}}$ & $56.60^{\mathrm{b}}$ & $50.37^{\mathrm{d}}$ & 1.47 \\
Protein & $13.90^{\mathrm{b}}$ & $15.68^{\mathrm{a}}$ & $16.36^{\mathrm{a}}$ & $10.77^{\mathrm{c}}$ & $10.32^{\mathrm{c}}$ & 0.67 \\
Fat & $7.71^{\mathrm{d}}$ & $7.96^{\mathrm{d}}$ & $9.21^{\mathrm{c}}$ & $14.41^{\mathrm{b}}$ & $17.28^{\mathrm{a}}$ & 1.70 \\
Total solids & $41.37^{\mathrm{b}}$ & $40.77^{\mathrm{b}}$ & $49.40^{\mathrm{a}}$ & $33.07^{\mathrm{c}}$ & $35.00^{\mathrm{c}}$ & 1.46 \\
Wet Cheese Yield $(\mathrm{g})$ & $285.40^{\mathrm{b}}$ & $243.50^{\mathrm{c}}$ & $336.40^{\mathrm{a}}$ & $223.87^{\mathrm{c}}$ & $163.30^{\mathrm{d}}$ & 3.21 \\
Wet Cheese Yield $(\%)$ & $28.54^{\mathrm{b}}$ & $24.35^{\mathrm{c}}$ & $33.64^{\mathrm{a}}$ & $22.39^{\mathrm{c}}$ & $16.33^{\mathrm{d}}$ & 3.20 \\
Dry cheese Yield $(\mathrm{g})$ & $117.50^{\mathrm{bc}}$ & $122.20^{\mathrm{b}}$ & $136.20^{\mathrm{a}}$ & $119.94^{\mathrm{c}}$ & $111.02^{\mathrm{c}}$ & 4.50 \\
Dry cheese Yield $(\%)$ & $11.75^{\mathrm{bc}}$ & $11.22^{\mathrm{b}}$ & $13.62^{\mathrm{a}}$ & $11.99^{\mathrm{c}}$ & $11.10^{\mathrm{c}}$ & 4.49 \\
\hline abcd & & & &
\end{tabular}

${ }^{\text {abcd }}$ Means in the same row with different superscript are significantly different $(\mathrm{P}>0.05)$

\section{Minerals}

From this study it was observed that as salt inclusion increases, sodium and chloride concentration of the final cheese increases (table 4) which is expected because of the liberation of more sodium and chloride ion into the cheese. Calcium concentration in cheese is determined by the quantity of Colloidal Calcium Phosphate (CCP) lost from the curd (Moller et al., 2013). This in turn depends on three principal factors $(\mathrm{pH}$ at whey drainage, cooking treatment and pre-acidification of the cheese milk) during cheese manufacture (Lucey and Fox, 1993). There was an increase in the calcium concentration of the cheese up to the inclusion level of $8 \mathrm{~g}$ however, additional increase in salt level beyond $8 \mathrm{~g}$ resulted in a reduced calcium concentration. This phenomenon could be as a result of the direct effect of sodium chloride on cheese texture and rheology, because sodium chloride addition increased the amount of the matrix as well as casein hydration and solubilization via calcium displacement (Rulikowska et al., 2013; Yuanrong et al., 2016). This report also agrees with Moller $e t$ al. (2013) who reported that as concentration of salt increases in cheese it will reach a point that the calcium content of the cheese will start to decrease because salt behaviour in cheese is concentrationdependent. In addition, the calcium reduction could be due to ion-exchange effect which implies that colloidal calcium may have been displaced by $\mathrm{Na}+$ ions 


\section{Koranteng, Awodoyin, Adediran and Omojola}

(Guinee and Fox, 2004) as observed between emulsifying salts and the casein matrix during cheese production. Another explanation for this may be that curd syneresis during salting and pressing favoured calcium losses in high-salt curds, which held more moisture (Møller et al.,
2012). However, additional calcium analysis of the whey at drainage, salting and pressing would have clarified the significance of the mechanisms in display. The phosphorus contents of cheese produced in this study did not follow a particular pattern.

Table 4: Mineral compositions of soft cheese with graded levels of sodium chloride

\begin{tabular}{lcccccc}
\hline Parameters $(\mathrm{ml})$ & $\mathrm{T}_{1}$ & $\mathrm{~T}_{2}$ & $\mathrm{~T}_{3}$ & $\mathrm{~T}_{4}$ & $\mathrm{~T}_{5}$ & $\mathrm{SEM}$ \\
\hline Calcium & $1.22^{\mathrm{b}}$ & $1.31^{\mathrm{b}}$ & $1.49^{\mathrm{a}}$ & $0.70^{\mathrm{c}}$ & $0.95^{\mathrm{c}}$ & 0.21 \\
Sodium & $0.14^{\mathrm{d}}$ & $0.22^{\mathrm{d}}$ & $0.31^{\mathrm{c}}$ & $0.39^{\mathrm{b}}$ & $0.48^{\mathrm{a}}$ & 0.01 \\
Chloride & $0.14^{\mathrm{e}}$ & $0.22^{\mathrm{d}}$ & $0.31^{\mathrm{c}}$ & $0.39^{\mathrm{b}}$ & $0.48^{\mathrm{a}}$ & 0.01 \\
Phosphorus & $0.78^{\mathrm{c}}$ & $1.44^{\mathrm{b}}$ & $1.54^{\mathrm{b}}$ & $0.51^{\mathrm{d}}$ & $2.35^{\mathrm{a}}$ & 0.01 \\
\hline
\end{tabular}

${ }^{\mathrm{abcd}}$ Means in the same row with different superscript are significantly different $(\mathrm{P}>0.05)$

\section{Texture profile analysis}

Texture is an important indicator for evaluating cheese quality and functional characteristics and it is considered to be a determinant of the overall opinion and preference of cheese consumers (Wendin et al., 2000; Foegeding et al., 2003). The quality (mostly texture and flavour) of cheese depends on the amount of salt added to the curd during cheese production (Fox et al., 2000). Texture profile analysis (TPA) has been reported to be effective for analyzing and predicting sensory attributes of cheese (Yuanrong et al., 2016). In this study it was observed that the cohesiveness and resilience of cheese decreases as the salt level increases while the elasticity, gumminess, chewiness and firmness increases as the salt level increases. However, increase in adhesiveness only occurred up to salt inclusion level of $8 \mathrm{~g}$ after which it starts to decrease. Adhesiveness was the degree to which the sample sticks to teeth as mastication progresses (Gwartney et al., 2004) and for cheese consumption, appropriate adhesiveness is good for taste and flavour releasing. It was noticed that cheese with high protein and low fat have high adhesiveness which was against the report of Yuanrong et al. (2016) who reported that lower protein and higher fat contents allow cheese to melt better and thus increase the adhesiveness.

Chewiness is a secondary textural parameters and it is a measure of the force needed to masticate a solid food to a state that it is ready for swallowing (Tunick, 2000). In sensory terms, it relates the number of chews that are required before the sample is ready for swallowing (Gwartney et al., 2004]. This study revealed that as the salt level increases, the chewiness of the cheese increases. From the result, it is expected that the chewiness of cheese with high salt should reduce due to the presence of high fat which will allow cheese to melt better (Yuanrong, et al. 2016) but the reverse was observed here. This could probably be due to the increase in the firmness (due to the low moisture contents) of the cheeses with high salt levels which implies that more chews will be required before swallowing. The report of this study agrees with Yuanrong et al. (2016) who reported a positive relationship between firmness and chewiness of cheese.

Elasticity referred to the degree to which food returns to its original shape after partial compression between the tongue and hard palate (Gwartney et al., 2004). In this study it was observed cheese with low calcium contents have higher elasticity and viceversa. This was against the report of Chevanan et al. (2006) who observed 
higher springiness/elasticity in highcalcium and high-phosphorus cheese through a testing period of eight months. This disparity might be attributed to the presence of gums (e.g., carrageenan and xanthan gum) that are usually used to maintain the springiness of cheese which might be present in the cheese studied by Chevanan et al. (2006). Firmness is the force needed to attain a given deformation (Tunick, 2000) and in sensory terms, it is the force required to compress food with the molars to the point of penetration (Szczesniak, 2002). In this study, it was observed that as the salt level increases, the firmness of the cheese also increases which corroborated the report that increase in salt level of cheese will result in low moisture contents (Irigoyen et al., 2002; Everard et al., 2007) thus more firm and compact cheese (Sandoval-Copad et al., 2016). However, the trend of the fat contents obtained in this study deviate from the report of Yuanrong et al. (2016) that cheese that is more firm and compact has low fat content.
Resilience refers to the degree to which the food regains its original shape during the biting process (Chevanan et al. 2006). Resilience is similar to springiness in describing cheese elasticity; however, there is a difference between them. Resilience measures the ability of the deformed cheese to return to its original position after removal of force rapidly while springiness or elasticity measures the ability of the deformed cheese to return to its initial position after removal of force slowly. In this study it was noticed that there was a slight increase although not significant in the resilience of the cheese as salt level increases from 4 to $8 \mathrm{~g}$ but a drastic reduction was observed with further addition of salt $(12 \mathrm{~g}$ and $16 \mathrm{~g})$. This implies that addition of salt beyond $8 \mathrm{~g}$ might result in a cheese that will be too mealy and will not be able to return back to its original position after removal of force. Again, it was expected that the cheese with high level of calcium should have a decline in resilience as reported by Yuanrong et al. (2016) but the opposite was observed in this study.

Table 5: Texture profile analysis of freshly prepared soft cheese as affected by graded levels of sodium chloride

\begin{tabular}{lcccccc}
\hline Parameters & $\mathrm{T}_{1}$ & $\mathrm{~T}_{2}$ & $\mathrm{~T}_{3}$ & $\mathrm{~T}_{4}$ & $\mathrm{~T}_{5}$ & $\mathrm{SEM}$ \\
\hline Adhesiveness & $2.20^{\mathrm{c}}$ & $3.20^{\mathrm{a}}$ & $2.87^{\mathrm{b}}$ & $1.53^{\mathrm{d}}$ & $1.47^{\mathrm{d}}$ & 0.097 \\
Chewiness & $1.27^{\mathrm{d}}$ & $1.47^{\mathrm{b}}$ & $1.53^{\mathrm{b}}$ & $1.67^{\mathrm{b}}$ & $2.20^{\mathrm{a}}$ & 0.089 \\
Cohesiveness & $4.33^{\mathrm{a}}$ & $4.07^{\mathrm{a}}$ & $3.93^{\mathrm{a}}$ & $1.27^{\mathrm{c}}$ & $1.47^{\mathrm{c}}$ & 0.183 \\
Elasticity & $3.47^{\mathrm{b}}$ & $3.53^{\mathrm{b}}$ & $3.07^{\mathrm{c}}$ & $4.53^{\mathrm{a}}$ & $4.64^{\mathrm{a}}$ & 0.119 \\
Firmness & $1.40^{\mathrm{c}}$ & $1.80^{\mathrm{c}}$ & $2.93^{\mathrm{b}}$ & $4.47^{\mathrm{a}}$ & $4.80^{\mathrm{a}}$ & 0.174 \\
Gumminess & $1.20^{\mathrm{c}}$ & $1.40^{\mathrm{c}}$ & $2.07^{\mathrm{b}}$ & $4.47^{\mathrm{a}}$ & $4.53^{\mathrm{a}}$ & 0.190 \\
Resilience & $0.11^{\mathrm{b}}$ & $0.89^{\mathrm{a}}$ & $0.90^{\mathrm{a}}$ & $0.05^{\mathrm{b}}$ & $0.08^{\mathrm{b}}$ & 0.090 \\
\hline
\end{tabular}

${ }_{\mathrm{abcd}}$ Means in the same row with different superscript are significantly different $(\mathrm{P}>0.05)$

\section{Conclusion}

Salt inclusion in cheese was inversely proportional to moisture content, adhesiveness and cohesiveness, but directly proportional to firmness, gumminess, chewiness and elasticity. The inclusion of salt $8 \mathrm{~g} / 1000 \mathrm{~mL}$ of milk favoured most of the indices measured (yield, protein, firmness, chewiness) implying that inclusion level up to this level is ideal in cheese production.

\section{References}

Abdel Moneim E. Sulieman., Rasha, A. Mohamed Ali., Kamal, A. Abdel Razig 2012. Production and Effect 


\section{Koranteng, Awodoyin, Adediran and Omojola}

of Storage in the Chemical Composition of Mozzarella Cheese. International Journal of Food Science and Nutrition Engineering 2(3): 21-26

AFNOR, 1985. Fromage. Détermination de la teneuren phosphate total. M é $\mathrm{t} \mathrm{hod} \mathrm{e} \quad \mathrm{p}$ a $\mathrm{r}$ spectrométried'absorption moléculaire. Norme NF V04-284

Ak, M. M. and Gunasekaran, S. 2002. Cheese Rheology and Texture, CRC Press

Akinloye, A. M. and Adewumi, O. O. 2014. Effects of local coagulants on the yield of cheese using cow and sheep milk, International. Journal of Development and Sustainability $3(1): 150-161$

AOAC 2000. Methods of Analysis: 18th Ed. Washington, DC: Association of Official Analytical Chemists.

Breslinm P. A. and Beauchamp, G. K. 1997. Salt enhances flavour by suppressing bitterness. Nature 387: 563-568.

Chevanan, N. Muthukumarappan, K. Upreti, P. and Metzger, L. E. 2006. Effect of calcium and phosphorus, residual lactose and salt-to-moisture ratio on textural properties of cheddar cheeseduringripenin. Journal of Texture Studies 37(6):711-730.

Coppola, R., Sorrention, E., Cinquanta, L., Lorrizo, M. and Grazia, L. 1995. Shelf life of mozzarella cheese samples packaged without liquid and stored at different temperatures. Italian Journal Food Science 7: 351-359.

El-Bakry, Mamdouh 2012 Salt in cheese: A review. Current research in dairy sciences 4 (1):1-5.

El Owni, O. A. O. and Sana, E. Osman 2009. Evaluation of chemical composition and yield of
Mozzarella cheese using two different methods of processing. Pakistan journal of Nutrition 8(5): 684-687.

ELKoussy, L. A., Mustafa, B. M., AbdelKader, Y. I. and Zoghby, A. S. 1995. Properties of mozzarella cheese as affected by milk type, yield recovery of milk and chemical composition of cheese. Proceeding of the 6th Egyptian Conference for Dairy Science and Technology, Cairo, Egypt, 4 - 6 November. Pages $121-132$.

Everard, C. D., O'Callaghan, D. J., O'Kennedy, B. T., O'Donnell, C. P., Sheehan, E. M. and Delahunty, C. M. 2007. A threepoint bending test for prediction of sensory texture in processed cheese. Journal of Texture Study. 38:438- 456.

Fasakin, A. and Unokiwedi, C. 1992. Chemical analysis of fermented cheese obtained from Cow milk and melon. Nigerian Journal of Microbiology 5: 559-566.

Fernadez, A. and Kosikowski, F. V. 1986. Low moisture mozzarella cheese from whole milk retentates of ultrafiltration. Journal Dairy Science 69:2011 - 2017.

Foegeding, E.A. Brown, J. Drake, M. and Daubert, C. R. 2003. Sensory and mechanical aspects of cheese texture.International Dairy Journal 13 (8):585-591.

Fox, P. F., Guinee, T. P., Cogan, T. M. and McSweeney, P. L. H. 2000. Fundamentals of cheese science, Aspen Publishers Inc., Maryland, US.

Frazier, W. C. and Westhoff, D. C. 1998. Food Microbiology. 4th ed. Tata McGraw Hill Publishing Ltd., New Delhi, pages 276-297.

Guinee, T. P. and Fox, P. F. 2004. Salt in 
cheese: Physical, chemical and biological aspects. In Cheese Chemistry, Physics and Microbiology. Vol. 1: General Aspects. 3rd ed. P. F. Fox, P. L. H. McSweeney, T. M. Cogan, and T. P. Guinee, ed. Elsevier Academic Press, San Diego, CA. Pages 207-259.

Guo, M. R. Gilmore, J. A. and Kindstedt, P. S. 1997. Effect of sodium chloride on the serum phase of mozzarella cheese. Journal of Dairy Science. 80: 3092-3098.

Gwartney, E. A., Larick, D. K. and Foegeding, E. A. 2004. Sensory texture and mechanical properties of stranded and particulate whey protein emulsion gels. Journal of Food Science 69 (9): S333-S339.

Habib, R. 2015. Effect of salting method on salt concentration in Dhaka cheese. Progressive Agriculture 26: 79-84.

Hussain, A., Hussain, A., Ahmad, B. and Rehman, M. F. 2014. Analysis of physicochemical stability of apricot pulp stored with chemical preservatives. International Journal Novel Res. Life Science 1: 17-23.

Irigoyen, A., Castiella, M. Ordonez, A. I. Torre, P. and Ibarez, F. C. 2002. Sensory and instrumental evaluations of texture in cheeses made from ovine milks with differing fat contents. Journal Sensory Study. 17:145-161.

ISO-IDF (International Organization for Standardization-International Dairy Federation). 2007 Milk and milk products-Determination of calcium, sodium, potassium and magnesium contents-Atomic absorption spectrometric method. ISO8070-IDF119. ISO, Geneva, Switzerland.

Lucey, J. A. and Fox. P. F. 1993.
Importance of calcium and phosphate in cheese manufacture: A review. Journal Dairy Science 76:1714-1724.

Madadlou A., Mausavi A., Khosroshahi S.M. and Djome, Z. E. 2006. Microstructure and rheological properties of Iranian white cheese coagulated at various temperatures. Journal of Dairy Science 89:23592364.

McCarthy, Catherine M., Wilkinson, Martin G., Kelly, Philip M. and Guinee, Timothy P. 2015. Effect of salt and fat reduction on the composition, lactose metabolism, water activity and microbiology of Cheddar cheese. Dairy Science and Technology. 95:587-611.

Møller, K. K., Rattray, F. P., Bredie, W. L. P., Høier, E. and Ardö, Y. 2012. Manufacture and biochemical characteristics during ripening of Cheddar cheese with variable $\mathrm{NaCl}$ and equal moisture content. Dairy Science Technology. 92:543-568.

Møller, K. K., Rattray, F. P., Bredie, W. L. P., Høier, E. and Ardö, Y. 2013. Physicochemical and sensory characterization of Cheddar cheese with variable $\mathrm{NaCl}$ levels and equal moisture content Journal Dairy Science 96:1953-1971.

Nour El Diam, M.S.A. and El Zubeir, Ibtisam, E. M. 2010. Chemical Composition of Processed Cheese Using Sudanese White Cheese. Research Journal of Animal and Veterinary Sciences 5:31-37.

Ogunlade A. O., Oyetayo, V. O. and Ojokoh, A. O. 2017. Percentage Yield and Proximate Composition of Cheese Produced from Sheep Milk Using Different Coagulants. International Journal of Microbiology and Biotechnology 2(4): 171-175. 
Paulson, B.M., McMahon, D. J. and Oberg, C. J. 1998. Influence of sodium chloride on appearance, functionality and protein arrangements in non-fat Mozzarella cheese. Journal Dairy Science 81: 2053-2064.

Rulikowska, A., Kilcawley, K. N. and Doolanetal, I. A. 2013. The impact of reduced sodium chloride content o $\mathrm{n} \mathrm{C} \mathrm{h} \mathrm{e} \mathrm{d} \mathrm{d} \mathrm{a} \mathrm{r} \mathrm{c} \mathrm{h} \mathrm{e} \mathrm{e} \mathrm{s} \mathrm{e}$ quality.International Dairy Journal 28(2):45-55.

S a ndoval-Copad o, J ., OrozcoVillafuerte, J. Pedrero-Fuehrer, D. and Colín-Cruz, M. A. 2016. Sensory profile development of Oaxaca cheese and relationship with physicochemical parameters. Journal Dairy Science 99:70757084

Shahein, M. R., Hassanein, A. M. and Zayan, A. F. 2014. Evaluation of soft cheese manufactured from camel and buffalo milk. World Journal Dairy Food Science 9: 213-219.

Szczesniak, A. S. 2002. Texture is a sensory property. Food Quality and Preference 13 (4): 215- 225.

Tunick, M. H. 2000. Rheology of dairy foods that gel, stretch, and fracture. Journal of Dairy Science. 83(8):1892-1898.

Uaboi-Egbmni, P. O., Okolie, P. N. Akintunde, T. L. Bisi-Johnson O., Enwe, L. N. and Bessong. P. O. 2010. Proximate Analysis and Microbiological Quality of Cheese Produced from Raw Cow Milk Obtained from Fulani Settlement in Ogun State Nigeria, Using Lactic Acid Bacteria and Extract from S o d o m A p l e L e a f (Calotropisprocera). Pakistan Journal of nutrition 9 (9): 920-925.
Upreti, P., Metzger, L. E. and Bühlmann, P. 2004. Glass and polymeric membrane electrodes for the measurement of $\mathrm{pH}$ in milk and cheese. Talanta 63:139-148.

Van Hekken, D. L., Park, Y. W. and Tunick, M. H. 2013. Effects of reducing fat content on the proteolytic and rheological properties of Cheddar-like caprine milk cheese. Small Ruminant Research 110(1): 46-51.

Wendin, K., Langton, M., Caous, L. and Hall, G. 2000. Dynamic analyses of sensory and microstructural properties of cream cheese. Food Chemistry 71(3): 363-378.

Yates, M. D. and Drake, M. A. 2007. Texture properties of Gouda cheese. Journal of Sensory Studies. $22(5): 493-506$.

Yuanrong, Z., Zhenmin, Liu and Beihong, Mo. 2016. Texture Profile Analysis of Sliced Cheese in relation to Chemical Composition and Storage Temperature.Journal of Chemistry 1-11.

Zisu, B., and Shah, N. P. 2005. Textural and functional changes in low fat Mozzarella cheeses in relation to proteolysis and microstructure as influenced by the use of fat replacers, pre-acidification and EPS starter. International Dairy Journal 15:957-972.

Received: $10^{\text {th }}$ March, 2021 Accepted: $15^{\text {th }}$ August, 2021 